\title{
Evaluation of Microbiological, Physicochemical, and Sensory Properties of Galbi-jjim Prepared by Sous-vide and Cookchill Method at Different Temperatures
}

\author{
Weon-Sun Shin*, Kyeong Mi Kim¹, Jin-Hee Park², and Taeim Cho \\ Laboratory of Food Chemistry, Department of Food and Nutrition, Hanyang University, Seoul 133-791, Korea \\ ${ }^{1}$ Research Institute of Food, OURHOME, Seongnam 462-819, Korea \\ ${ }^{2}$ Food R\&D Lab, R\&D Center, DAESANG Corp., Icheon 467-813, Korea
}

\begin{abstract}
The aim of this study was to evaluate the physico-chemical, sensory, and microbiological properties of ready-to-eat Korean traditional seasoned beef ribs ("galbi-jjim") prepared by sous-vide/cookchill technology during storage at three different temperatures $\left(4,10\right.$, and $\left.20^{\circ} \mathrm{C}\right)$. Beef short ribs marinated in soy sauce for $24 \mathrm{~h}$ at $3{ }^{\circ} \mathrm{C}$ were packed with vegetables under vacuum. Vacuum-packed beef ribs mixed with vegetables were heated at $90^{\circ} \mathrm{C}$ for $90 \mathrm{~min}$ in a water bath, and then immediately chilled below $3^{\circ} \mathrm{C}$ within $120 \mathrm{~min}$ in an ice slurry. Physicochemical ( $\mathrm{pH}$, water activity, TBARS, L*a*b* color, and texture profile), sensory (appearance, odor, flavor, texture, and acceptance) and microbiological (Coliform, Escherichia coli, food-borne pathogenic bacteria) properties of the samples were determined during storage at different temperatures. Results showed that $\mathrm{pH}, \mathrm{a}_{\mathrm{w}}$, and sensory evaluation of products were not affected in any consistent way as a function of either storage duration or temperature. Coliform, E. coli and food-borne pathogens were not detected during storage at any temperature. However, TBARS significantly increased during storage period $(p<0.05)$. Based on TBARS values, SV/CC "galbi-jjim" can be stored for $15 \mathrm{~d}, 12 \mathrm{~d}$ and $1 \mathrm{~d}$ at 4,10 and $20^{\circ} \mathrm{C}$, respectively.
\end{abstract}

Key words: sous-vide/cook-chill, sensory quality, microbiological safety, temperature abuse simulation

\section{Introduction}

Many Korean traditional dishes require time-consuming and intensive labor for preparation and cooking (Paik et al., 2006), whereas they have limited storage stability at normal refrigeration temperature. Consumers demand foods that are convenient, easy to prepare, high quality and preservative-free (Galimpin-Johan et al., 2007; Koo et al., 2008; Paik et al., 2006). As two-income households, working mothers, singles, and seniors have increased, the market for convenient food has grown remarkably. Consequently, the production of intermediate food or ready-to-eat meals in cold chain have became more popular compared to traditional home-cooked meal (Johnson and Resurreccion, 2009).

Sous-vide/cook-chill (SV/CC) technology is a cooking procedure originated in France in the mid-1970s. SV/CC

\footnotetext{
*Corresponding author: Weon-Sun Shin, Laboratory of Food Chemistry, Department of Food and Nutrition, Hanyang University, Seoul 133-791, Korea. Tel: 82-2-2202-1204, Fax: 82-2-2292-1226, E-mail: hime@hanyang.ac.kr
}

system is defined as raw or par-cooked foods are vacuum-sealed in a barrier pouch or container, cooked slowly in controlled mild heating conditions, rapidly chilled, stored at refrigeration temperatures and reheated for consumption (Creed, 1998; Ghazala et al., 1995; Schellekens, 1996; SVAC, 1991). SV/CC technology is applied to catering industries, food service sectors and ready meal-type food productions (Creed, 1998; Vaudagna et al., 2002).

Previous studies (González-Fandos et al, 2004; Schellekens, 1996) have shown that SV/CC technology is possible to extend the shelf-life from 6 to $42 \mathrm{~d}$. SV/CC applied foods are generally processed using a mild heat treatment and requires a long heating time at low temperature to retain tenderness, juiciness and microbiological safety (bacterial pathogens).

As the poiuts of the quality, SV/CC is a highly advanced technology because of convenience, better sensory quality and retention of water-soluble nutrition than conventional cooked food (Schellekens, 1996; Vaudagna et al., 2008). Nevertheless, anaerobic and temperature abuse conditions of SV/CC cooked foods can cause potential 
microbiological hazards during the product circulation and at the consumer level (Schellekens, 1996; Tansey et al., 2005). In our previous report, the optimal textural and sensory conditions of SV/CC processing were investigated to develop the ready-to-eat (RTE) Korean tradition "galbi-jjim" (Kim, Park and Shin, 2009). As a result, the control temperatures of SV/CC processed "galbi-jjim" satisfied the guidelines of ACMSF (Advisory Committee on the Microbiological Safety of Food, U.K., 2004), ECFF (European Chilled Food Federation, U.K., 1996), Food code (FDA, U.S.A., 2005) and DHSS (Department of Health and Social Security, U.K., 2003).

Therefore, the objective of this study was to evaluate the physico-chemical, sensory quality and microbiological safety of the ready-to-eat (RTE) type "galbi-jjim" product at normal refrigeration temperature $\left(4^{\circ} \mathrm{C}\right)$ and temperatureabused conditions $\left(10^{\circ} \mathrm{C}\right.$ and $\left.20^{\circ} \mathrm{C}\right)$ (FDA, USA, 2005; ACMSF, UK, 2004) for industrial application.

\section{Materials and Methods}

\section{Preparation of sous-vide "galbi-jjim"}

Beef short ribs for sous-vide/cookchill were purchased from a local market (Seoul, Korea) and cut into $4.9 \times 3.1 \times$ $3 \mathrm{~cm}$ pieces. The SV/CC "galbi-jjim" was processed as shown in Fig. 1. Briefly, the beef short ribs were submerged in cold water for $2 \mathrm{~h}$ to remove blood and cooked in boiling water for $60 \mathrm{~min}$. The pre-cooked beef short ribs were marinated in seasoning sauce for $24 \mathrm{~h}$ at $3^{\circ} \mathrm{C}$ before vacuum packing. Beef short ribs and vegetables (carrots, gingko nuts, taro, and shiitake mushrooms) were vacuum-packed in nylon/ PE/ LLDPE pouch (Samhosa Co., Ltd., Seoul, Korea) using a vacuum sealing machine (SH-100/SMV-206T, Samhosa Co., Ltd., Seoul, Korea) under $760 \mathrm{~mm} \mathrm{Hg}$ pressure. The products were cooked at $90^{\circ} \mathrm{C}$ for $90 \mathrm{~min}$ in a water-bath with a meat core temperature of $85^{\circ} \mathrm{C} / 60 \mathrm{~min}$ and immediately chilled in an ice slurry jacket until the internal temperature reached $\leq 3^{\circ} \mathrm{C}$ within $1 \mathrm{~h}$.

The pasteurization and chilling method was followed to UK ACMSF (2004), UK ECFF (1996), FDA (2005) and UK DHSS (2003) guidelines. Chilled products were stored at $4^{\circ} \mathrm{C}$ (FRB-4230N, Daewoo, Seoul, Korea), $10^{\circ} \mathrm{C}$ and $20^{\circ} \mathrm{C}$ (Temperature \& Timer controller; HB-103S, Han Baek Scientific Co., Seoul, Korea) for $36 \mathrm{~d}$ for sensory evaluation, physicochemical and microbiological analysis.

\section{Physicochemical analysis}

Water activity, $\mathrm{pH}, 2$-thiobarbituric acid reactive sub-

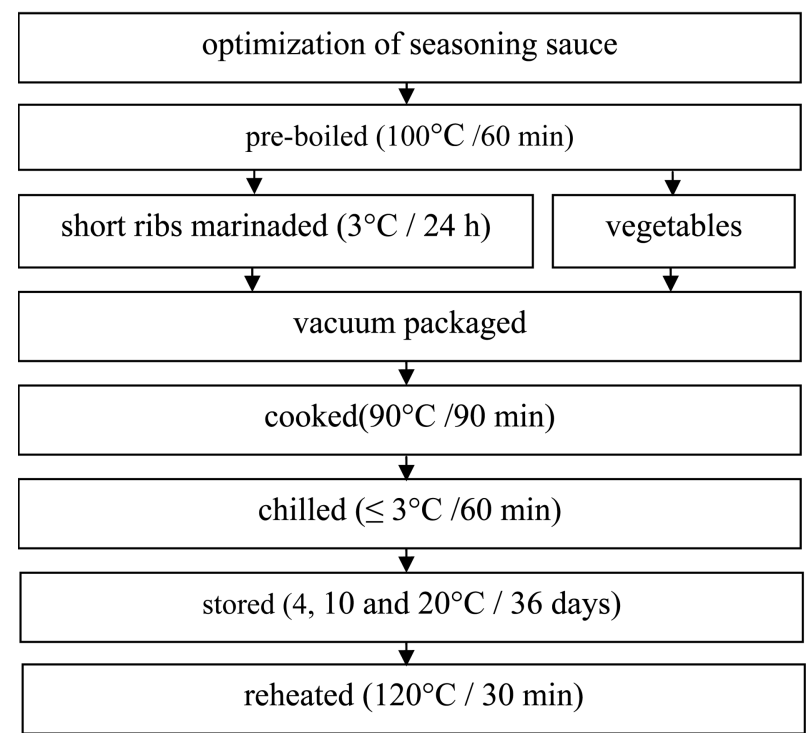

Fig. 1. The sous-vide/cookchill process of Korean traditional galbi-jjim.

stances (TBARS), CIE L ${ }^{*} a^{*} b^{*}$ color and texture profile were performed during storage (3-d intervals) at 4,10 and $20^{\circ} \mathrm{C}$. The products stored at $4^{\circ} \mathrm{C}$ and $10^{\circ} \mathrm{C}$ were analyzed after 1, 3, 6, 9, 12, 15, 18, 21, 24, 27, 30, 33 and $36 \mathrm{~d}$, and those at $20^{\circ} \mathrm{C}$ were analyzed after $1,3,6,9,12$ and $15 \mathrm{~d}$.

The water activity $\left(\mathrm{a}_{\mathrm{w}}\right)$ was determined by the Conway Unit Method (Sibata Scientific Technology Ltd., Tokyo, Japan). Three gram of potassium dichromate (regent A) and potassium mitrate (reagent B) was pur into the outside cell, separately. A sample (1 g) was placed in an aluminum weighing case and the lid, and closed to stand in a thermostat at $25( \pm 2)^{\circ} \mathrm{C}$ for $2( \pm 0.5)$ hours. The water activity $\left(\mathrm{a}_{\mathrm{w}}\right)$ value was calculated according to the following equations:

$$
\begin{aligned}
& a_{w}=B \times X-A \times Y / X-Y \\
& A: a_{w} \text { value of regent (wet) A } \\
& B: a_{w} \text { value of regent (wet) B } \\
& X: \text { increase or decrease of weight with A } \\
& \text { Y: increase or decrease of weight with A }
\end{aligned}
$$

The pH measurements (Vaudagna et al., 2008) were performed with a $\mathrm{pH}$ meter (Model M530 Pinnacle, Corning, USA). A sample ( $5 \mathrm{~g}$ ) was mixed with distilled water $(25 \mathrm{~mL})$ for $30 \mathrm{sec}$ using a blender (HMF-505, Hanil Electric Inc., Bucheon, Korea) and filtered through Whatman filter paper No. 2 (Advantec No. 2/ TY2, Toyo, Japan).

TBARS was determined by a modification of the previous methods (Choi et al., 2002; Witte et al., 1970). The 
refrigerated sample $(5 \mathrm{~g})$ was mixed with $12.5 \mathrm{~mL}$ of $20 \%$ trichloroacetic acid in $2 \mathrm{M}$ phosphoric acid and homogenized with $10 \mathrm{~mL}$ of distilled water for about 40 seconds in a blender (HMF-505, Hanil Electric Inc., Bucheon, Korea). The distilled water was added until the volume reached to $25 \mathrm{~mL}$, centrifuged at $1500 \mathrm{rpm}$ for 15 min using a centrifuge (VS-21SMTi, High Speed Refrigerated Centrifuge, Vision, Seoul, Korea), and filtered (No. 1, Whatman International Ltd., Maidstone, UK). The filtered solution $(2 \mathrm{~mL})$ was mixed with $2 \mathrm{~mL}$ of fresh $0.005 \mathrm{M}$ 2-thiobarbituric acid solution (TBA) and left for $15 \mathrm{~h}$ at room temperature for reaction. The absorbance was measured at $530 \mathrm{~nm}$ with a spectrophotometer (Ultrospec $^{\circledR} 2100$ pro, Biochrom, UK), and the TBARS value was calculated according to the following equations:

TBARS (mg malonaldehyde/kg sample)

$=$ Absorbance at $530 \mathrm{~nm} \times 5.2$

The meat color was measured both on the surface and in a cross section of cut meat into half with a color meter (Minolta CR-400, Minolta Co., Ltd., Japan). Color was recorded with the Hunter $\mathrm{L}^{*}$ value (darkness to lightness), $a^{*}$ value (greenness to redness) and $b^{*}$ value (blueness to yellowness) scale and the instrument was calibrated using a white standard tile prior to use. The calibration value was 96.03 at $\mathrm{L}^{*}$ value, 0.16 at a value and 2.07 at $\mathrm{b}^{*}$ value. Triplicate readings per product were performed.

Hardness of the beef short rib was tested using a TA.XT 2i/25 texture analyzer (Stable Micro system, London, UK) during the storage period at room temperature. Beef short ribs were cut into $1.5 \times 1.5 \times 1.5 \mathrm{~cm}$ and measurements were conducted using an aluminum cylinder probe with $2 \mathrm{~cm}$ in diameter. The measuring condition was followed as below pre-test speed: $3.0 \mathrm{~mm} / \mathrm{s}$, test speed: $1.0 \mathrm{~mm} / \mathrm{s}$, post-test speed: $1.0 \mathrm{~mm} / \mathrm{s}$, strain: $80 \%$, time: $2.0 \mathrm{~s}$ and force: $5.0 \mathrm{~g}$. The hardness of beef short rib was expressed as kilogram $(\mathrm{kg})$. The entire experiments are conducted in triplicate.

\section{Sensory analysis}

The sensory evaluation of the samples stored for 0 (freshly cooked "galbi-jjim"), 7, 14, and $21 \mathrm{~d}$ was conducted. The period of the sensory test was set by preliminary tests in our laboratory. The intensity sensory evaluation was carried out by 35 panelists from Hanyang University students (Seoul, Korea). Prior to serving to the panelists, each product was reheated reaching to $75^{\circ} \mathrm{C}$ or above (DHSS, 2003) of internal temperature within 30 min in the combination oven (CS-0405, Daeyung Bakery Machinery Ind., Co., Ltd., Seoul, Korea). The sample was placed on white lidded pottery with random three-digit numbers after removal of bone from sample and cut into $1.5 \times 1.5 \times 1.5 \mathrm{~cm}$ cubes. The panelists evaluated the reheated Galbi-jjim using a 15 point structured scale and the scales used for the sensory evaluation were the following: meat color $(1=$ very light to $15=$ very dark $)$, ingredient color $(1=$ extremely invisible to $15=$ extremely visible $)$, oxidized odor (extremely weak to 15 = extremely strong), off-flavor, off-taste, meat juiciness, saliness $(1=$ extremely weak to $15=$ extremely strong) and overall acceptance $(1=$ dislike extremely to $15=$ like extremely $)$.

\section{Microbiological analysis}

To determine the microbial quality of stored products, $25 \mathrm{~g}$ of sample were aseptically weighed and homogenized in a stomacher (BagMixer ${ }^{\circledR} 400$, Interscience, France) for 2 min with $225 \mathrm{~mL}$ of $0.1 \%$ peptone water (Difco, Detroit, MI, USA). Decimal serial dilutions in $0.1 \%$ peptone water were used for quantification. Cell counts of Escherichia coli and coliform were determined on Petrifilm $^{\mathrm{TM}}$ E. coli/Coliform Count Plate (PEC) (3M, St. Paul, USA). All the samples were analyzed in triplicate.

Other pathogenic bacteria (Shigella spp., E. coli O157: H7, Staphylococcus aureus, Bacillus cereus, Vibrio parahaemolyticus, Listeria monocytogenes, Yersinia enterocolitica, Salmonella spp.) were detected using PCR assay (Powerchek $^{\mathrm{TM}}$ Multiplex-Pathogen Detection kit, Kogene, Seoul, Korea). For the PCR of the enriched sample, $1 \mathrm{~mL}$ of enrichment culture was collected after $24 \mathrm{~h}$ of incubation. The subsample was centrifuged at 12,000 rpm for 5 min by using microcentrifuge (Micro 17R, Hanil Science Industrial, Korea). The supernatant was carefully removed, and the precipitants were washed twice, and then re-suspended in sterile distilled water. After the suspension was heated at $95^{\circ} \mathrm{C}$ for $5 \mathrm{~min}$ and centrifuged at $10,000 \mathrm{rpm}$ for $10 \mathrm{~min}$, the supernatant was frozen at $-20^{\circ} \mathrm{C}$. One $\mu \mathrm{L}$ of positive control 1 (E. coli $\mathrm{O} 157: \mathrm{H7}$, Bacillus cereus, Listeria monocytogenes, Salmonella spp.) or control 2 (Shigella spp., Staphylococcus aureus, Vibrio parahaemolyticus, Yersinia enterocolitica) DNA template was mixed with $9 \mu \mathrm{L}$ of sterile distilled water and $10 \mu \mathrm{L}$ of sterile distilled water was used as a negative control instead of a DNA template. Positive control, negative control and sample DNA template were added to $15 \mu \mathrm{L}$ of primer master mix and amplificated by PCR (MyCyclerTM Personal thermal cycler, Bio-Rad, CA, USA). Amplification conditions were: $5 \mathrm{~min}$ at $94^{\circ} \mathrm{C}, 40$ cycles 
of $30 \mathrm{~s}$ at $94^{\circ} \mathrm{C}, 30 \mathrm{~s}$ at $60^{\circ} \mathrm{C}$ and $30 \mathrm{~s}$ at $72^{\circ} \mathrm{C}$ and a final extension of $5 \mathrm{~min}$ at $94^{\circ} \mathrm{C}$. PCR products were electrophoresed through $2 \%$ agarose $\left(\mathrm{SeaKem}{ }^{\circledR} \mathrm{LE}\right.$ agarose, Lonza, USA) gel in a TBE buffer (AccuGENE, Lonza, USA).

\section{Statistical analysis}

One-Way Analysis of variance data was done using SPSS for Windows 13.0 (SPSS Institute, Chicago, IL, USA) with a factor for storage days. The intensity sensory anaysis was determined Multivariate Analysis of Variance (MANOVA). Means $\pm \mathrm{SD}$ was calculated by Duncan's Multiple Range Test at $p<0.05$.

\section{Results and Discussion}

\section{pH and water activity $\left(a_{w}\right)$}

Water activity was not changed as the storage time and temperature increased (Fig. 2).

Fig. 3 shows the $\mathrm{pH}$ of products measured during storage. The $\mathrm{pH}$ values of samples stored at any temperatures were not significantly $(p<0.05)$ different time increased. This result was similar to other reports for SV/CC cooked meat-based products (Galimpin-Johan et al., 2007; Jang and Lee, 2005).

\section{TBARS}

TBARS values of galbi-jjims were measured at the interval of $3 \mathrm{~d}$ during storage at three different temperatures are shown in Fig. 4. In several studies, TBARS value of meat increased during storage (Witte et al., 1970) and lipid oxidation in cooked meats stored at an

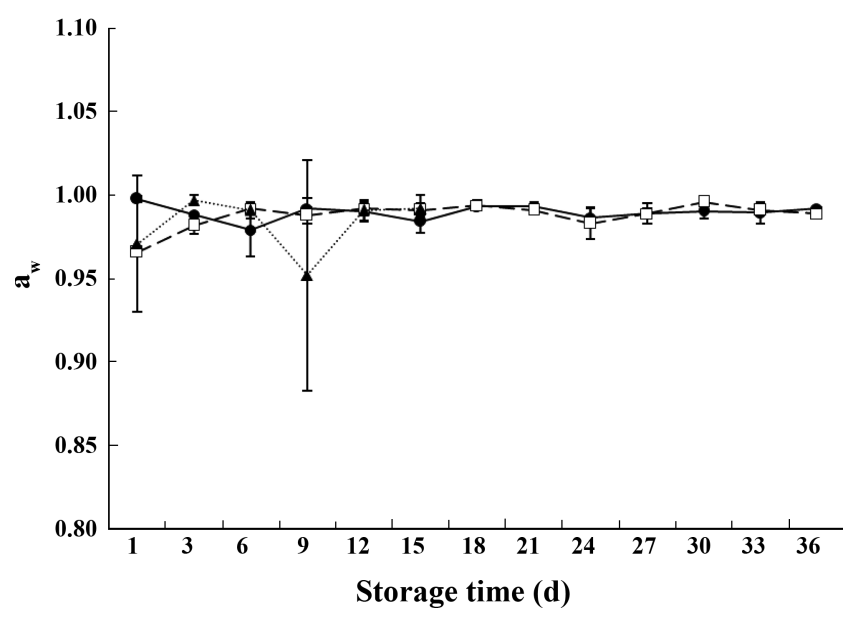

Fig. 2. Change of $a_{w}$ values in Galbi-jijim by sous-vide/cookchill system during storage at $4^{\circ} \mathrm{C}(\odot), 10^{\circ} \mathrm{C}(\square)$ and $20^{\circ} \mathrm{C}(\Delta)$.

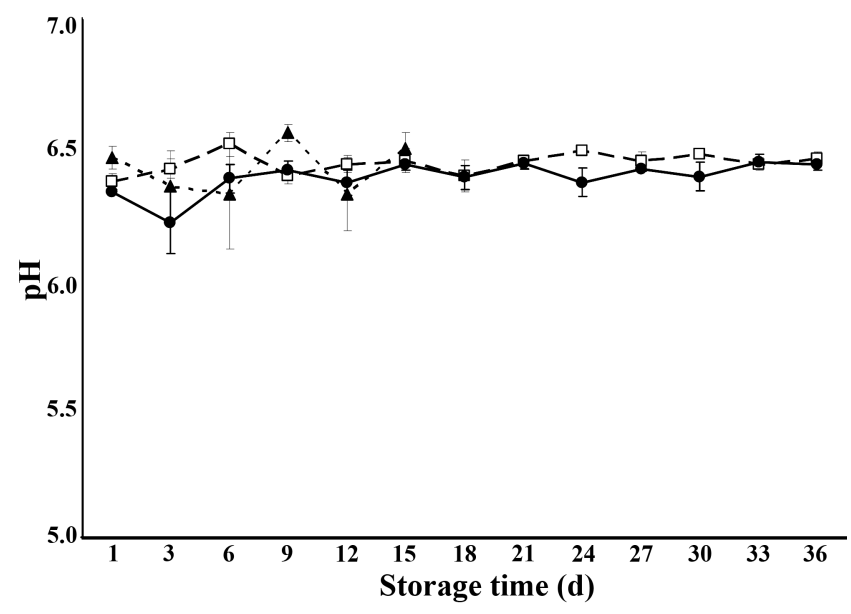

Fig. 3. Change of pH values of beef short rib in Galbi-jjim by sous-vide/cookchill system during storage at $4^{\circ} \mathrm{C}(\bigcirc)$, $10^{\circ} \mathrm{C}(\square)$ and $20^{\circ} \mathrm{C}(\Delta)$.

improper temperature during storage increased (Igene and Pearson, 1979). Fanco (2002) has reported that TBARS value is usually below $0.46 \mathrm{mg} \mathrm{MDA} / \mathrm{kg}$ in raw meat and Turner (1954) has shown that the lipid oxidation value of decayed food was $1.2 \mathrm{mg} \mathrm{MDA} / \mathrm{kg}$. Also, several researchers (Chang and Chen, 1998; Moon et al., 2006) have reported that TBARS value of Korean seasoned meat was high due to some ingredients derived from Korean traditional ingredients such as soy sauce, garlic and ginger. In this study, the TBARS values of Galbi-jjim stored at $4^{\circ} \mathrm{C}$ significantly increased $(p<0.00001)$. The initial TBARS value was $0.62 \mathrm{mg} \mathrm{MDA} / \mathrm{kg}$ and then was over $1 \mathrm{mg}$ MDA $/ \mathrm{kg}$ after $15 \mathrm{~d}$. After $36 \mathrm{~d}$ of storage, the TBARS value of Galbi-jjim reached $4.13 \mathrm{mg}$ MDA $/ \mathrm{kg}$. TBARS

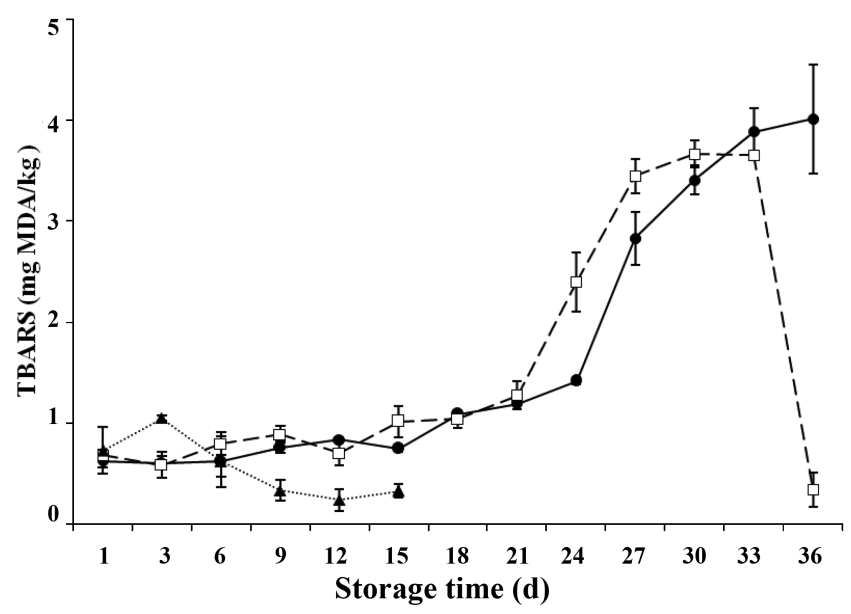

Fig. 4. Change of thiobarbituric acid reactive substance (TBARS) values in Galbi-jjim by sous-vide/cookchill system during storage at $4^{\circ} \mathrm{C}(\bigcirc), 10^{\circ} \mathrm{C}(\square)$ and $20^{\circ} \mathrm{C}$ (A). 
values of galbi-jjim stored at $10^{\circ} \mathrm{C}$ significantly changed over time $(p<0.00001)$. The values increased until $30 \mathrm{~d}$, but rapidly decreased from $3.65 \mathrm{mg} \mathrm{MDA} / \mathrm{kg}$ to $0.33 \mathrm{mg}$ MDA $/ \mathrm{kg}$ after $33 \mathrm{~d}$. This result has been in good agreement with Gokalp et al. (1983) and Laleye et al. (1984), which TBARS values increased due to the formation of malondialdehydrate (MDA) at initial storage, but decreased by combining with amino acid or carbonyl compounds in the meat product after a certain period. When galbi-jjims were improperly abused at $20^{\circ} \mathrm{C}$, TBARS value reached to $1.06 \mathrm{mg} \mathrm{MDA} / \mathrm{kg}$ after $3 \mathrm{~d}$, suggesting that malondialdehydrate more rapidly reacted at $20^{\circ} \mathrm{C}$ than at $4^{\circ} \mathrm{C}$ and $10^{\circ} \mathrm{C}$. Thus, this result shown that TBARS value mainly depends on both storage temperature and time.

\section{Hardness}

The hardness of galbi-jjim stored at different temperatures was measured with time course. Statisyically, the storage time did not influence on the change in hardness of galbi-jjim samples at any temperatures $(p<0.05)$. Although, the measurements in hardness of galbi-jjim samples stored at different temperatures were repeated more than 10 times, the precisive and homogeneous data among the samples were not obtained as shown in Fig. 5. Therefore, we confered that meat used for galbi-jjim preparation caused to produce uneven and statisticall insignificant data.

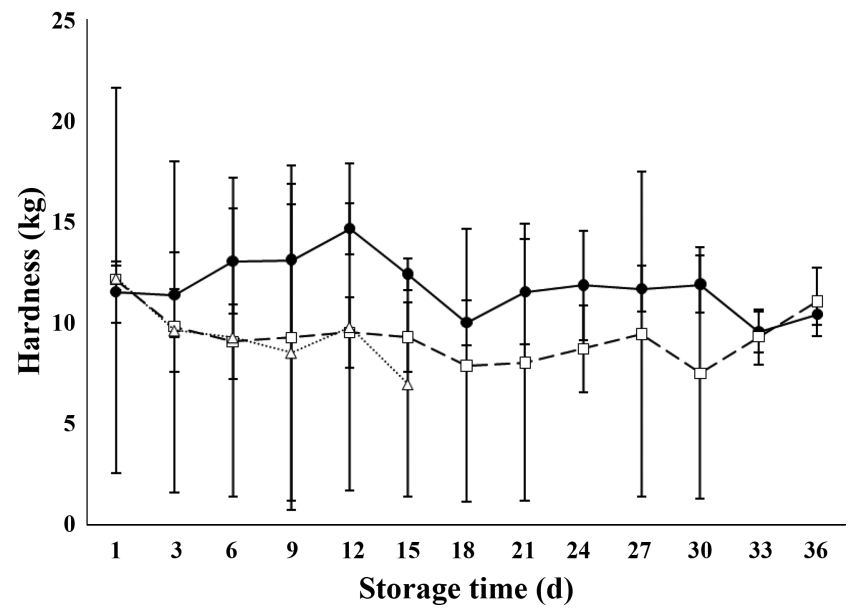

Fig. 5. Change in hardness of galbi-jjim by sous-vide/cookchill system during storage at $4^{\circ} \mathrm{C}(\bigcirc), 10^{\circ} \mathrm{C}(\square)$ and $20^{\circ} \mathrm{C}(\Delta)$.

\section{Color}

The surface colors of the meat samples were shown in Table 1(A). L (lightness) and $\mathrm{a}^{*}$ (redness) value of beef short rib slowly increased with storage days at $4^{\circ} \mathrm{C}$. At $10^{\circ} \mathrm{C}$, the $\mathrm{L}^{*}$ values were not changed for $18 \mathrm{~d}$, but significantly increased from $22 \mathrm{~d}$ (27.26) to $32 \mathrm{~d}$ (38.08) $(p<0.05)$. And, $\mathrm{L}^{*}$ value of galbi-jjims stored at $20^{\circ} \mathrm{C}$ was not significantly changed $(p>0.05)$ but $\mathrm{a}^{*}$ values markedly $(p<0.05)$ increased during storage period. However, Fu et al. (1992) reported that $\mathrm{L}^{*}$ and $\mathrm{a}^{*}$ values were decreased by producing peptides and amino acids because of the

Table 1(A). Change in surface colors of Galbi-jjim by sous-vide/cookchill system during storage

\begin{tabular}{|c|c|c|c|c|c|c|c|c|c|c|c|}
\hline \multirow{2}{*}{$\begin{array}{c}\text { Surface } \\
\text { color }\end{array}$} & \multicolumn{11}{|c|}{ Storage d } \\
\hline & $1 \mathrm{~d}$ & $4 \mathrm{~d}$ & $8 \mathrm{~d}$ & $11 \mathrm{~d}$ & $15 \mathrm{~d}$ & $18 \mathrm{~d}$ & $22 \mathrm{~d}$ & $25 \mathrm{~d}$ & $29 \mathrm{~d}$ & $32 \mathrm{~d}$ & $36 \mathrm{~d}$ \\
\hline $\mathrm{L}^{*} 4^{\circ} \mathrm{C}$ & $28.37 \pm 2.66^{\mathrm{a}}$ & $30.78 \pm 0.76^{\mathrm{a}}$ & $34.18 \pm 5.29^{\mathrm{a}}$ & $31.71 \pm 4.55^{\mathrm{a}}$ & $34.03 \pm 1.64^{\mathrm{a}}$ & $31.76 \pm 3.69^{\mathrm{a}}$ & $32.27 \pm 1.25^{\mathrm{a}}$ & $34.86 \pm 3.31^{\mathrm{a}}$ & $30.64 \pm 5.40^{\mathrm{a}}$ & $29.38 \pm 2.98^{\mathrm{a}}$ & $34.33 \pm 1.14^{\mathrm{a}}$ \\
\hline $10^{\circ} \mathrm{C}$ & $32.13 \pm 2.92^{\mathrm{b}}$ & $31.90 \pm 0.62^{\mathrm{b}}$ & $31.93 \pm 3.36^{\mathrm{b}}$ & $29.78 \pm 3.65^{\mathrm{b}}$ & $31.65 \pm 3.70^{\mathrm{b}}$ & $30.46 \pm 2.24^{\mathrm{b}}$ & $27.26 \pm 4.97^{\mathrm{b}}$ & $29.72 \pm 2.62^{b}$ & $32.91 \pm 1.78^{\mathrm{ab}}$ & $38.08 \pm 0.34^{\mathrm{a}}$ & $28.80 \pm 1.50^{\mathrm{b}}$ \\
\hline $20^{\circ} \mathrm{C}$ & $29.82 \pm 3.19^{\mathrm{a}}$ & $29.77 \pm 2.44^{\mathrm{a}}$ & $32.11 \pm 0.78^{\mathrm{a}}$ & $30.99 \pm 2.16^{\mathrm{a}}$ & $30.68 \pm 1.81^{\mathrm{a}}$ & $29.82 \pm 4.84^{\mathrm{a}}$ & & & & & \\
\hline$a^{*} 4^{\circ} \mathrm{C}$ & $4.67 \pm 1.18^{\mathrm{ab}}$ & $6.63 \pm 0.38^{\mathrm{a}}$ & $5.53 \pm 1.48^{\mathrm{bc}}$ & $4.54 \pm 0.61^{\mathrm{ab}}$ & $3.47 \pm 0.31^{\mathrm{a}}$ & $5.95 \pm 0.85^{\mathrm{bc}}$ & $5.68 \pm 0.11^{\mathrm{bc}}$ & $6.24 \pm 1.05^{\mathrm{a}}$ & $6.01 \pm 0.44^{\mathrm{bc}}$ & $6.38 \pm 0.91^{\mathrm{a}}$ & $6.99 \pm 0.29^{\mathrm{a}}$ \\
\hline $10^{\circ} \mathrm{C}$ & $4.69 \pm 2.27^{\mathrm{ab}}$ & $4.41 \pm 0.64^{\mathrm{c}}$ & $4.92 \pm 0.67^{\mathrm{ab}}$ & $5.88 \pm 1.03^{\mathrm{ab}}$ & $4.67 \pm 1.50^{\mathrm{ab}}$ & $5.10 \pm 0.67^{\mathrm{ab}}$ & $6.21 \pm 1.46^{\mathrm{ab}}$ & $5.82 \pm 0.55^{\mathrm{ab}}$ & $6.08 \pm 0.57^{\mathrm{ab}}$ & $6.98 \pm 0.60^{b}$ & $5.17 \pm 1.12^{\mathrm{a}}$ \\
\hline $20^{\circ} \mathrm{C}$ & $6.53 \pm 0.90^{\mathrm{bc}}$ & $6.11 \pm 0.62^{\mathrm{c}}$ & $8.58 \pm 0.99^{\mathrm{bc}}$ & $8.26 \pm 1.11^{\mathrm{abc}}$ & $8.50 \pm 1.78^{\mathrm{bc}}$ & $6.53 \pm 1.69^{\mathrm{a}}$ & & & & & \\
\hline
\end{tabular}

Data are mean \pm SD.

${ }^{\mathrm{abc}}$ Different letters are significantly different $(p<0.05)$ by Duncan's test.

Table 1(B). Change in inner colors of Galbi-jjim by sous-vide/cookchill system during storage

\begin{tabular}{|c|c|c|c|c|c|c|c|c|c|c|c|}
\hline \multirow{2}{*}{$\begin{array}{l}\text { Inner } \\
\text { color }\end{array}$} & \multicolumn{11}{|c|}{ Storage d } \\
\hline & $1 \mathrm{~d}$ & $4 \mathrm{~d}$ & $8 \mathrm{~d}$ & $11 \mathrm{~d}$ & $15 \mathrm{~d}$ & $18 \mathrm{~d}$ & $22 \mathrm{~d}$ & $25 \mathrm{~d}$ & $29 \mathrm{~d}$ & $32 \mathrm{~d}$ & $36 \mathrm{~d}$ \\
\hline $\mathrm{L}^{*} 4^{\circ} \mathrm{C}$ & $32.11 \pm 2.66^{\mathrm{a}}$ & $34.68 \pm 0.76^{\mathrm{a}}$ & $34.34 \pm 5.29^{\mathrm{a}}$ & $36.99 \pm 4.55^{\mathrm{a}}$ & $34.78 \pm 1.64^{\mathrm{a}}$ & $34.03 \pm 3.69^{\mathrm{a}}$ & $36.88 \pm 1.25^{\mathrm{a}}$ & $35.74 \pm 3.31^{\mathrm{a}}$ & $33.31 \pm 5.40^{\mathrm{a}}$ & $34.23 \pm 2.98^{\mathrm{a}}$ & $33.96 \pm 1.14^{\mathrm{a}}$ \\
\hline $10^{\circ} \mathrm{C}$ & $38.27 \pm 2.92^{\mathrm{ab}}$ & $35.06 \pm 0.62^{\mathrm{b}}$ & $33.03 \pm 3.36^{\mathrm{bc}}$ & $35.34 \pm 3.65^{\mathrm{b}}$ & $25.47 \pm 3.7^{\mathrm{b}}$ & $33.21 \pm 2.24^{\mathrm{bc}}$ & $33.59 \pm 4.97^{\mathrm{bc}}$ & $29.13 \pm 2.62^{c}$ & $37.17 \pm 1.78^{\mathrm{ab}}$ & $41.51 \pm 0.34^{\mathrm{a}}$ & $32.97 \pm 1.50^{\mathrm{bc}}$ \\
\hline $20^{\circ} \mathrm{C}$ & $36.19 \pm 3.58^{\mathrm{a}}$ & $35.64 \pm 2.84^{\mathrm{a}}$ & $37.72 \pm 2.56^{\mathrm{a}}$ & $35.76 \pm 2.64^{\mathrm{a}}$ & $34.45 \pm 1.17^{\mathrm{ab}}$ & $36.19 \pm 1.58^{\mathrm{b}}$ & & & & & \\
\hline$a^{*} 4^{\circ} \mathrm{C}$ & $6.74 \pm 1.18^{\mathrm{a}}$ & $7.12 \pm 0.38^{\mathrm{a}}$ & $8.18 \pm 1.48^{\mathrm{a}}$ & $7.22 \pm 0.61^{\mathrm{a}}$ & $8.32 \pm 0.31^{\mathrm{a}}$ & $7.71 \pm 0.85^{\mathrm{a}}$ & $7.64 \pm 0.11^{\mathrm{a}}$ & $6.99 \pm 1.05^{\mathrm{a}}$ & $7.01 \pm 0.44^{\mathrm{a}}$ & $7.90 \pm 0.91^{\mathrm{a}}$ & $8.29 \pm 0.29^{\mathrm{a}}$ \\
\hline $10^{\circ} \mathrm{C}$ & $8.55 \pm 2.27^{b}$ & $7.15 \pm 0.64^{\text {bc }}$ & $8.16 \pm 0.67^{\mathrm{bc}}$ & $6.98 \pm 1.03^{\mathrm{bc}}$ & $7.91 \pm 1.50^{\mathrm{bc}}$ & $6.21 \pm 0.67^{\mathrm{c}}$ & $7.55 \pm 1.46^{\mathrm{bc}}$ & $8.08 \pm 0.55^{\mathrm{bc}}$ & $7.75 \pm 0.57^{\mathrm{bc}}$ & $7.45 \pm 0.60^{\mathrm{bc}}$ & $8.32 \pm 1.12^{\mathrm{a}}$ \\
\hline $20^{\circ} \mathrm{C}$ & $7.38 \pm 1.15^{\mathrm{b}}$ & $7.61 \pm 0.56^{\mathrm{b}}$ & $8.34 \pm 1.18^{\mathrm{b}}$ & $7.89 \pm 0.34^{\mathrm{b}}$ & $8.22 \pm 1.31^{\mathrm{b}}$ & $7.38 \pm 2.23^{\mathrm{a}}$ & & & & & \\
\hline
\end{tabular}

Data are mean \pm standard deviation

${ }^{a b c}$ Different letters are significantly different $(p<0.05)$ by Duncan's test. 
degradation of proteins during aging. The $b^{*}$ values (yellowness) of galbi-jjims stored at $4^{\circ} \mathrm{C}$ for $4 \mathrm{~d}$ were significantly higher than $1 \mathrm{~d}$, but decreased during storage (Data not shown).

Table 1(B) shows the change of the inner color in the $\mathrm{SV} / \mathrm{CC}$ processed galbi-jjim. During storage, $\mathrm{L}^{*}$ (lightness) values and $\mathrm{a}^{*}$ (redness) values were not significantly changed at $4^{\circ} \mathrm{C}$, whereas products at $10^{\circ} \mathrm{C}$ and $20^{\circ} \mathrm{C}$ were significantly changed $(p<0.05)$. At $10^{\circ} \mathrm{C}, \mathrm{L}^{*}$ (lightness) values of inner beef color significantly decreased for $15 \mathrm{~d}$ (38.27 to 25.47), but increased after $15 \mathrm{~d}$ and a $^{*}$ (redness) values were slightly changed. At $20^{\circ} \mathrm{C}, \mathrm{L}^{*}$ (lightness) values decreased and $\mathrm{a}^{*}$ (redness) values increased during storage.

\section{Sensory analysis}

The sensory qualities of sous-vide galbi-jjim were shown in Fig. 6. The vales of saltiness, meat color and meat flavor were significantly changed between 0 to $3 \mathrm{wk}$ $(p<0.05)$ but, the scores of ingredient color, meat texture, oxidized odor, off-flavor and off-taste, meat juiciness and overall acceptance were not changed during storage. Oxidized odor, off-flavor, off-taste values were increased, but not significantly changed $(p<0.05)$. The scores of meat juiciness and overall acceptance were decreased during storage, but were not significantly different $(p<0.05)$.

\section{Microbiological analysis}

Microbiological analysis of the samples stored at $4^{\circ} \mathrm{C}$ and $10^{\circ} \mathrm{C}$ were performed at the interval of $3 \mathrm{~d}$ for $36 \mathrm{~d}$. At $20^{\circ} \mathrm{C}$, samples were analyzed until $15 \mathrm{~d}$ because of swelling of packages. Generally, a high number of coliforms and detection of $E$. coli in food reflects poor hygienic handling during the production process, inappropriate storage conditions and post-process contamination (Ghazala et al., 1995; Keeratipibul et al., 2009). After being stored for $1 \mathrm{~d}$, coliform and $E$. coli were not detected in any of the samples at 4,10 and $20^{\circ} \mathrm{C}$ and it was demonstrated that SV/CC "galbi-jjim" was properly produced. At 4 and $10^{\circ} \mathrm{C}$, microbial growth was not observed until $36 \mathrm{~d}$ (Fig. 7). Also, after storage at $20^{\circ} \mathrm{C}$ until $15 \mathrm{~d}$, coliform and $E$. coli were not detected, even though packs were visibly swollen. In addition, Food-borne pathogenic bacteria (Shigella spp., E. coli O157:H7, S. aureus, B. cereus, V. parahaemolyticus, L. monocytogenes, $Y$. enterocolitica, Salmonella spp.) were not detected during storage at any temperature. These results are in agreement with those reported by Jang and Lee (2005), who also found similar aerobic and anaerobic bacteria growth in sous-vide Korean seasoned beef at $4^{\circ} \mathrm{C}$ and

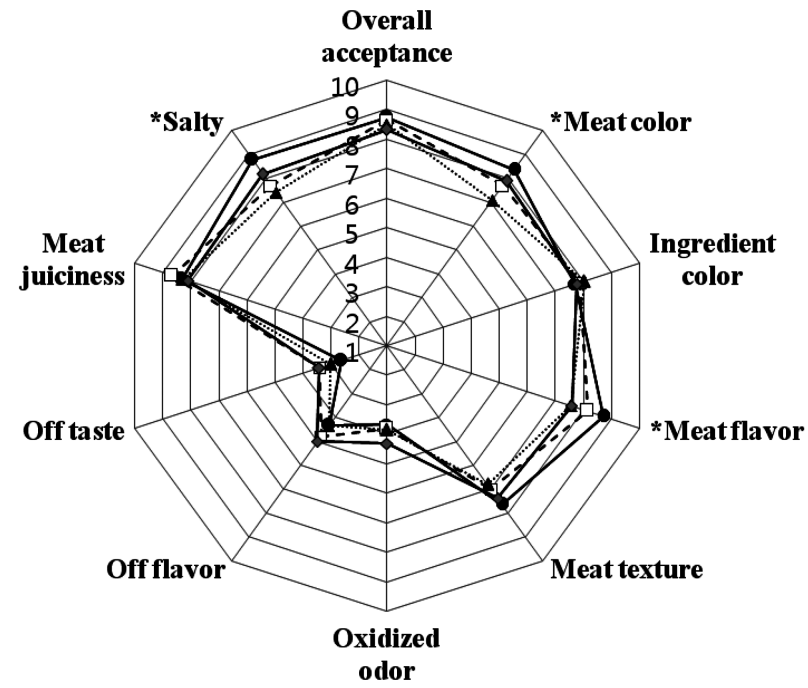

Fig. 6. Change in sensory quality of Galbi-jjim by sous-vide/ cookchill system during storage at $4^{\circ} \mathrm{C} .0 \mathrm{wk}(\bullet), 1 \mathrm{wk}$ $(\square), 2 \mathrm{wk}(\mathbf{\Delta})$ and $3 \mathrm{wk}(\diamond)$.

$10^{\circ} \mathrm{C}$ during the storage, but, bacteria started to grow at $20^{\circ} \mathrm{C}$ after $9 \mathrm{~d}$ of storage. Also, Gonzalez-Fandos (2004) reported that other anaerobic or facultative anaerobic bacteria were found at $20^{\circ} \mathrm{C}$ during the storage. In general, since temperature abuses can happen during the products distribution, retail or consumer level, the storage temperature cannot guarantee microbiological safety of SV/CC products. Additional hurdles like low $\mathrm{pH}, \mathrm{a}_{\mathrm{w}}$ and high $\mathrm{NaCl}$ contents should be applied. At 4,10 and $20^{\circ} \mathrm{C}$, other pathogenic bacteria except Shigella spp. were not detected during storage periods. However, Shigella spp. was detected after $36 \mathrm{~d}$ at $4^{\circ} \mathrm{C}$ and $10^{\circ} \mathrm{C}$ and $1 \mathrm{~d}$ at $20^{\circ} \mathrm{C}$. Even though raw materials were appropriately stored $\left(-20^{\circ} \mathrm{C}\right.$ in vacuum packaging) and heat treatment was applied according to ACMSF (2004) and ECFF (1996) guidelines, samples can be contaminated during production due to utensils and environmental condition such as air. To ensure microbiological safety of sous-vide products in mass production, Hazard Analysis Critical Control Point (HACCP) system should be applied (Gonzalez-Fandos et al., 2004).

\section{Conclusion}

Our study has shown that the proper storage of vacuum-packaged and cooked galbi-jjim at $4^{\circ} \mathrm{C}$ and $10^{\circ} \mathrm{C}$ did not lead to the hygienic and pathogenic microbiological growth during storage. Also, the qualities in the physicochemical properties such as $\mathrm{pH}$ and water activity of sous-vide processed galbi-jjim were not changed during storage at $4^{\circ} \mathrm{C}$ and $10^{\circ} \mathrm{C}$, and the sensory qualities were 

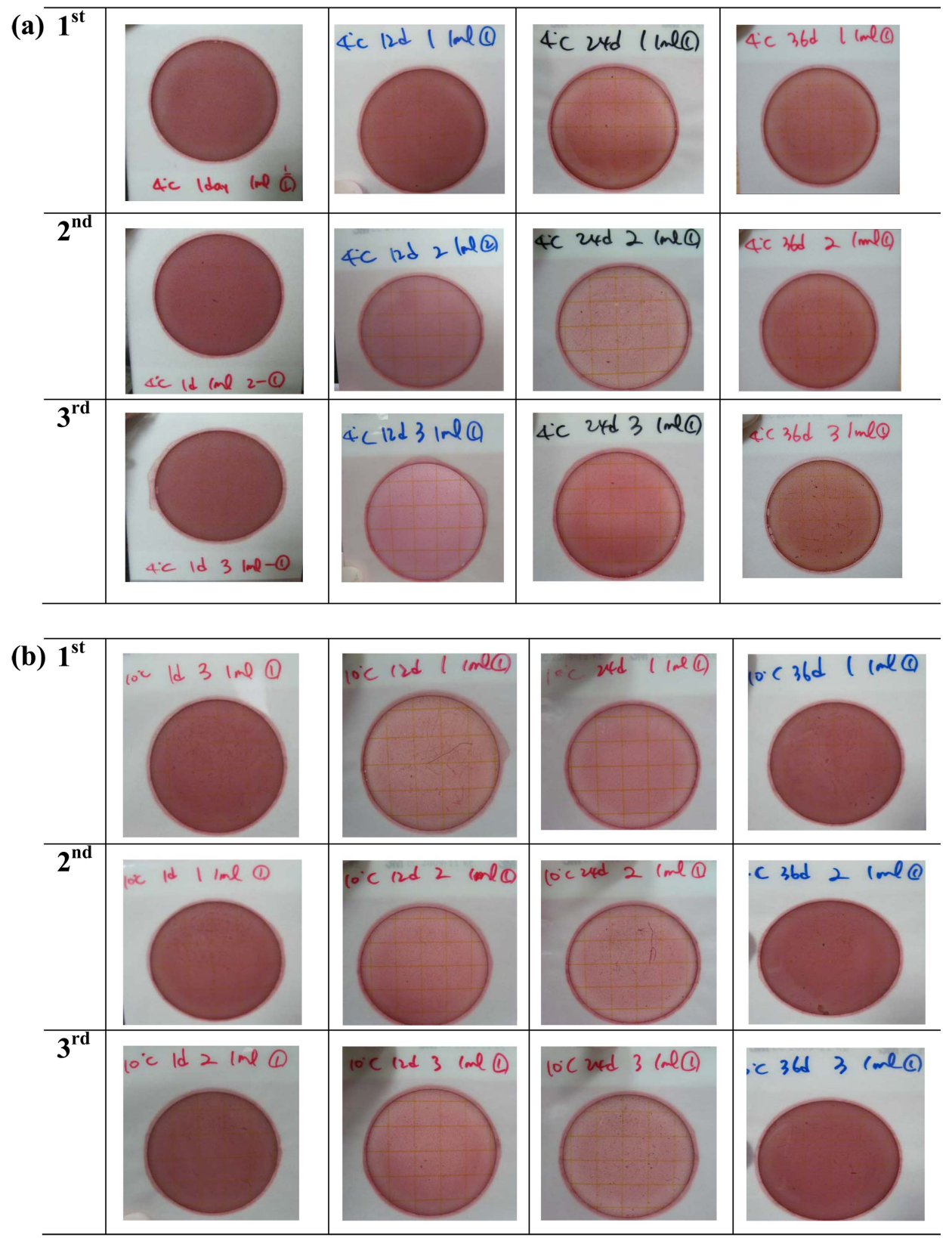

Fig. 7. E. coli and coliform counts of galbi-jjim by sous-vide/cookchill system for $36 \mathrm{~d}$ at $4^{\circ} \mathrm{C}(\mathrm{A})$ and $10^{\circ} \mathrm{C}(\mathrm{B})$.

not affected by storage time and temperature. However, the TBARS values of galbi-jjims stored at different temperatures significantly increased with storage time $(p<$ 0.05). The hardness of galbi-jjim stored at $10^{\circ} \mathrm{C}$ and $20^{\circ} \mathrm{C}$ were lower at refrigerating temperature $\left(4^{\circ} \mathrm{C}\right)$. This study suggested that sous-vide/cookchill processing can provide a microbiologically safe quality of RTE food products for a relatively long period.

\section{Abbreviations}

SV/CC, sous-vide and cook-chill; RTE, ready-to-eat;
ACMSF, advisory committee on the microbiological safety of food; ECFF, european chilled food federation; DHSS, department of health and social security; PE, polyethylene; LLDPE, linear low density polyethylene; TBARS, thiobarbituric acid reactive substance; TBA, thiobarbituric acid; PCR, polymerase chain reaction; TBE, tris/borate/EDTA; HACCP, hazard analysis and critical control points.

\section{Acknowledgement}

This work was supported by a Korean Research Foun- 
dation Grant funded by the republic of Korea Goverment (No. C00288).

\section{References}

1. ACMSF (2004) Discussion paper. In: Advisory Committee on the Microbiological Safety of Food (ACMSF), HMSO, London, UK.

2. Chang, M. H. and Chen, T. C. (1998) "Hotness" stability of chicken hot-wing products as affected by preparation methods and storage. Poultry Sci. 77, 627-631.

3. Choi, Y. S., Cho, S. H., Lee, S. K., Kim, B. C., and Rhee, M. S. (2002) Meat color, TBARS and VBN changes of vacuum packaged Korean pork loins for export during cold storage. Korean J. Food Sci. Ani. Resour. 22, 158-163.

4. Creed, P. G. and Reeve, W. (1998) Sensory and nutritional aspects of sous vide processed foods. In Sous vide and cookchill processing for the food industry. Ghazala S. (ed), Aspen Publishers, Gaithersburg, USA

5. DHSS (2003) Code of Practice No 9, In Process Control Cook Chill; Policy for Food Hygiene, Pest Control, Safety and Quality. Shropshire, UK: Shropshire County Primary Care NHS Trust.

6. Díaz, P., Nieto, G., Garrido, M. D., and Bañón, S. (2008) Microbial, physical-chemical and sensory spoilage during the refrigerated storage of cooked pork loin processed by the sous vide method. Meat Sci. 80, 287-292.

7. ECFF (1996) Guidelines for the hygienic manufacture of chilled foods. In: European Chilled Food Federation (ECFF), London, UK.

8. Fanco, I., Prieto, B., Cruz, J. M., Lopez, M., and Carballo, J. (2002) Study of the biochemical changes during the processing of Androlla, a Spanish dry-cured pork sausage. Food Chem. 78, 339-345.

9. Fu, A. H., Molins, R. A., and Sebranek, J. G. (1992) Storage quality characteristics of beef rib eye steaks packaged in modified atmospheres. J. Food Sci. 57, 283-287.

10. Galimpin-Johan, S. M. C., Rahman, R. A., Jamilah, B., Che Man, Y. B., and Rusul, G. (2007) Pasteurization, development and storage of sous vide rendang (spicy beef stew). Journal of Foodservice 18, 251-263.

11. Ghazala, S., Ramaswamy, H. S., Smith, J. P., and Simpson, M. V. (1995) Thermal-process simulations for sous vide processing of fish and meat foods. Food Res. Int. 8, 117-122.

12. Gokalp, H. Y., Ockerman, H. W., Plimpton, R. F., and Harper, W. J. (1983) Fatty acids of neutral and phospholipids, rancidity scores and TBA values as influenced by packaging and storage. J. Food Sci. 48, 829-834.

13. González-Fandos, E., García-Linares, M. C., Villarino-Rodriguez, A., Garcia-Arias, M. T., and Garcia-Fernandez, M. C. (2004) Evaluation of the microbiological safety and sensory quality of rainbow trout (Oncorhynchus mykiss) processed by the sous vide method. Food Microbiol. 21, 193-201.

14. Igene, J. O. and Pearson, A. M. (1979) Role of phospholipids and triglycerides in warmed-over flavor development in meat model systems. J. Food Sci. 44, 1285-1290.
15. Jang, J. D. and Lee, D. S. (2005) Development of a sous-vide packaging process for Korean seasoned beef. Food Control 16, 285-291.

16. Johnson, A. M. and Resurreccion, A. V. A. (2009) Sensory profiling of electron-beam irradiated ready-to-eat poultry frankfurters. LWT-Food Sci. Technol. 42, 265-274.

17. Keeratipibul, S., Techaruwichit, P., and Chaturongkasumrit, Y. (2009) Contamination sources of coliforms in two different types of frozen ready-to-eat shrimps. Food Control 20, 289-293.

18. Kim, K. M., Park, J. H., and Shin, W. S. (2009) Optimized conditions of model processing for ready-to-eat style galbijjim prepared by sous-vide and cook-chill system. Korean J. Food Sci. Ani. Resour. 29, 673-679

19. Koo, K. M., Kim, H. W., Lee, D. S., Lyu, E. S., and Paik, H. -D. (2008) Quality changes during storage of cook-chilled soybean sprouts. Food Sci. Biotechnol. 17, 540-546.

20. Laleye, L. C., Lee, B. H., Simard, R. E., Carmichael, L., and Holley, R. A. (1984) Shelf life of vacuum- or nitrogenpacked pastrami: Effects of packaging atmospheres, temperature and duration of storage on microflora changes. J. Food Sci. 49, 827-831.

21. Moon, S. S., Jin, S. K., Kim, I. S., Park, K. H., and Hah, K. H. (2006) Changes of TBARS, VBN and pathogens on vacuum packed pork during storage after aging with Korean traditional sauces. Korean J. Food Sci. Ani. Resour. 26, 322-330.

22. Paik, H. -D., Kim, H. -J., Nam, K. -J., Kim, C. -J., Lee, S. E., and Lee, D. -S. (2006) Effect of nisin on the storage of sous vide processed Korean seasoned beef. Food Control 17, 994-1000.

23. Schellekens, M. (1996) New research issues in sous-vide cooking. Trends Food Sci. Tech.7, 256-262.

24. SVAC (1991) Code of Practice for Sous Vide Catering Systems. In. Tetbury, Gloucestershire, UK.

25. Tansey, F., Gormley, R., Carbonell, S., Oliveria, J., Bourke, P., and O'Beirne, D. (2005) Developing sous vide/freezing systems for ready-meal components. In A. a. F. D. Authority. Dublin, Ireland: The national food center.

26. Turner, E. W., Paynter, W. D., Montie, E. J., Bassert, M. W., Struck, G. M., and Olson, F. C. (1954) Use of 2-thiobarbituric acid reagent to measure rancidity of frozen pork. Food Technol-Chicago 8, 326-354.

27. Vaudagna, S. R., Pazos, A. A., Guidi, S. M., Sanchez, G., Carp, D. J., and Gonzalez, C. B. (2008) Effect of salt addition on sous vide cooked whole beef muscles from Argentina. Meat Sci. 79, 470-482.

28. Vaudagna, S. R., Sanchez, G., Neira, M. S., Insani, E. M., Picallo, A. B., Gallinger, M. M., and Lasta, J. A. (2002) Sous vide cooked beef muscles: effects of low temperature-long time (LT-LT) treatments on their quality characteristics and storage stability. Int. J. Food Sci. Tech. 37, 425-441.

29. Witte, V. C., Krause, G. F., and Bailey, M. E. (1970) A new extraction method for determining 2-thiobarbituric acid values of pork and beef during storage. J. Food Sci. 35, 582-588.

$\overline{\text { (Received 2010.4.19/Revised 2010.7.24/Accepted 2010.8.31) }}$ 